\title{
Lack of business planning: A barrier to successful implementation of total quality management in South African agricultural small-, micro- and medium-sized enterprises
}

\begin{tabular}{|c|c|}
\hline \multicolumn{2}{|c|}{$\begin{array}{l}\text { Authors: } \\
\text { Awonke Sonandi }{ }^{1} \text { ( } \\
\text { Mmboswobeni W. Ladzani } \\
\text { Eric J. Nealer }{ }^{3}\end{array}$} \\
\hline \multicolumn{2}{|c|}{$\begin{array}{l}\text { Affiliations: } \\
\text { 1Eastern Cape Departmen } \\
\text { Rural Development and } \\
\text { Agrarian Reform, Bisho, } \\
\text { South Africa }\end{array}$} \\
\hline \multicolumn{2}{|c|}{$\begin{array}{l}{ }^{2} \text { Department of Business } \\
\text { Management, College of } \\
\text { Economic and Management } \\
\text { Sciences, University of South } \\
\text { Africa, Pretoria, South Africa }\end{array}$} \\
\hline \multicolumn{2}{|c|}{$\begin{array}{l}{ }^{3} \text { Department of Public } \\
\text { Administration and } \\
\text { Management, College of } \\
\text { Economic and Management } \\
\text { Sciences, University of South } \\
\text { Africa, Pretoria, South Africa }\end{array}$} \\
\hline \multicolumn{2}{|c|}{$\begin{array}{l}\text { Corresponding author: } \\
\text { Mmboswobeni Ladzani, } \\
\text { wladzani@unisa.ac.za }\end{array}$} \\
\hline \multicolumn{2}{|c|}{$\begin{array}{l}\text { Dates: } \\
\text { Received: } 20 \text { Jan. } 2021 \\
\text { Accepted: } 04 \text { Aug. } 2021 \\
\text { Published: } 27 \text { Oct. } 2021\end{array}$} \\
\hline \multicolumn{2}{|c|}{$\begin{array}{l}\text { How to cite this article: } \\
\text { Sonandi A, Ladzani MW, } \\
\text { Nealer EJ. Lack of business } \\
\text { planning: A barrier to } \\
\text { successful implementation of } \\
\text { total quality management in } \\
\text { South African agricultural } \\
\text { small-, micro- and medium- } \\
\text { sized enterprises. } \\
\text { J transdiscipl res S Afr. } \\
\text { 2021;17(1), a1013. } \\
\text { https://doi.org/10.4102/ } \\
\text { td.v17i1.1013 }\end{array}$} \\
\hline \multicolumn{2}{|l|}{ Read online: } \\
\hline 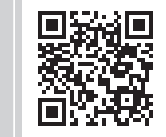 & $\begin{array}{l}\text { Scan this QR } \\
\text { code with your } \\
\text { smart phone or } \\
\text { mobile device } \\
\text { to read online. }\end{array}$ \\
\hline
\end{tabular}

This study aimed to establish baseline data for performance concerning the business planning function of agricultural small-, micro- and medium-sized enterprises (Agri-SMMEs) in the Eastern Cape Province, South Africa. It also endeavoured to investigate the extent to which AgriSMMEs that had adopted total quality management (TQM) had improved their business planning performance. An action research design and mixed methods, which included the internationally recognised South African Excellence Model (SAEM), were used to collect qualitative and quantitative data from Agri-SMMEs in the Western Eastern Cape (WEC) that had adopted the TQM philosophy, as well as from WEC and Eastern Eastern Cape (EEC) Agri-SMMEs that had not adopted that philosophy. Whether or not they had adopted TQM, the Agri-SMMEs studied were performing poorly relating to the business planning function when benchmarked against world-class standards. Hence, Agri-SMMEs that had implemented the TQM process did not necessarily have a performance advantage over those that had not adopted the process. With respect to practical implications, the use of the SAEM for continuous performance improvement of the business planning function should be promoted and interventions should be provided for the identified shortcomings relevant to this function. It is the first study of its kind to be conducted in the agricultural sector in South Africa. Therefore, the findings should provide a useful guide to enterprises contemplating implementing a TQM programme.

Keywords: total quality management(TQM); South African Excellence Model(SAEM); business planning; agricultural small-, micro- and medium-sized enterprises (Agri-SMMEs); business excellence models; continuous performance improvement.

\section{Introduction}

As a result of the previous apartheid regime, South Africa still has a dual agricultural sector. On the one hand, it comprises integrated commercial and prosperous agri-businesses, which are mainly in the hands of a minority of the population, and poorly resourced and trained farmers and producers with little or no access to the benefits of the mainstream agricultural sector on the other. $^{1,2}$ The operations of the latter group of farmers are often relatively small. Hence, they are commonly called small-scale farmers or agricultural small-, micro- and medium-sized enterprises (Agri-SMMEs), as they are referred to in this article.

In addition to the above historical challenges, South Africa's Agri-SMMEs face today's challenges caused by globalisation, changing customer needs and competition, amongst other factors. ${ }^{3}$ Ironically, these challenges also promote production of quality products or services, ${ }^{4,5}$ which in turn provide producers with an industrial competitive advantage. Accordingly, South Africa's Department of Agriculture, recently renamed the Department of Agriculture, Land Reform and Rural Development, introduced a total quality management (TQM) programme amongst selected Agri-SMMEs in the Eastern Cape (EC) province ${ }^{6}$ between 2006 and 2010. The implementation of the TQM programme sought to achieve the following objectives:

- To enhance the capacity of Agri-SMMEs to become better organised and better resourced with capital, technology and business management skills.

- To integrate previously disadvantaged Agri-SMMEs in the broader economic mainstream.

- To inculcate a culture of organisational excellence in the Agri-SMME band. 
In pursuit of achieving these objectives, it was envisaged that Agri-SMMEs would enhance their key role in the South African economy contributing, amongst other things, to employment provision, income generation and the provision of food security. Essentially, the welfare and livelihoods of most rural dwellers depend on Agri-SMMEs.

Over the 4-year TQM implementation period, the AgriSMMEs that had adopted the process were also presented with a TQM-based quality model called the South African Excellence Model (SAEM). In applying the model, the AgriSMMEs were expected to continuously self-assess their business performance and their status concerning the implementation of the TQM programme.

Notwithstanding the above developments, the researchers found no literature on studies that investigated the implementation of TQM in the Agri-SMME band in South Africa. As a result, there is a lack of information on the effects of implementing the TQM process in the agricultural sector in general, and in the Agri-SMME band in particular. This study thus raised the question of the extent to which South African Agri-SMMEs perform a strategic business planning (SBP) function, which is one of the many functions included in the SAEM (see Figure 1). ${ }^{7}$
It would be beneficial to explain the origin of and motivation for choosing the SAEM before progressing with this article.

The SAEM was developed in 1997. It came about after extensive national and international consultation with organisations that used the European Foundation for Quality Management (EFQM) and Malcolm Baldridge National Quality Award (MBNQA) models to assess excellence in organisational management systems. Similarities between the two quality frameworks necessitated that they be merged to produce a hybrid framework suitable for South African conditions. The 'Founding Champions' of the SAEM were: Armscor, CSIR - Council for Science and Industrial Research, Eskom, Greater Pretoria Metropolitan Council, Honeywell Southern Africa, IDEAS Management Southern Africa, Mercedes-Benz South Africa, SABS - South African Bureau of Standards, South African Quality Institute, South African Society for Quality and the Standard Bank of South Africa. Further to the 'Founding Champions', the following organisations later joined the 'Founding Champions' and were collectively referred to as the 'Founding Members', namely: ABSA Bank, Ingersoll-Rand Southern Africa and TSA - Technikon South Africa. ${ }^{8,9,10,11}$

The SAEM is regarded as the best model to assess excellence with respect to the TQM framework because of its non-

\begin{tabular}{|l|l|}
\hline 2011 & SA excellence model (1997) \\
\hline
\end{tabular}

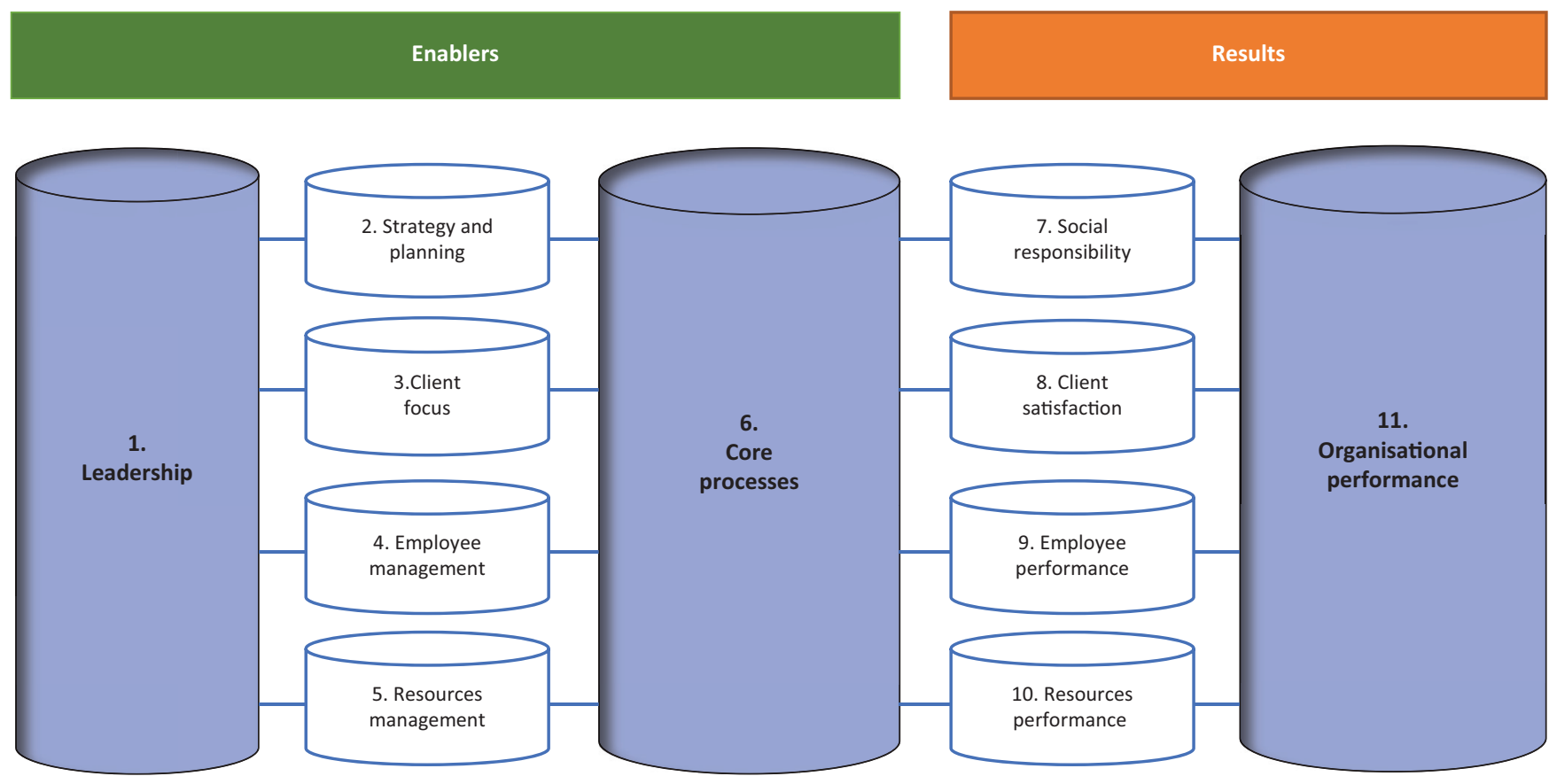

Source: Adapted from South African Excellence Foundation (SAEF). SME criteria for small and medium enterprise performance excellence. Pretoria: K \& M Print cc.; 2000

Criteria and weighted points (in brackets): 1 - Leadership (100 points), 2 - Policy \& Strategy (70), 3 - Customer \& Market Focus (60), 4 - People Management (90), 5 - Resources \& Information Management (60), 6 - Processes (120), 7 - Social Responsibility (60), 8 - Customer Satisfaction (170), 9 - People Satisfaction (90), 10 - Suppliers \& Partnership Performance (30), 11 - Business Results (150). Total points: 1000 (at Level 1).

FIGURE 1: The South African Excellence Model. 
prescriptive quality framework for self-assessment used to identify organisational strengths and areas for improvement. Having merged the best quality models in the world (the EFQM and MBNQA) in developing the model, makes it second to none.

In view of the above background, the objectives of this study were two-fold. Firstly, it sought to establish baseline data for performance concerning the SBP function of Agri-SMMEs in the EC province, South Africa, by employing the SAEM. Secondly, it endeavoured to investigate the extent to which Agri-SMMEs that had adopted TQM had improved their performance relevant to the SBP function.

The National Small Business Act 102 of 1996 classifies the agricultural sector in terms of enterprise size, either annual turnover or gross assets, or the size of the full-time workforce. For the purposes of this study, Agri-SMMEs are, therefore, defined as small-scale farmers, smallholders or owners/ managers of poorly resourced enterprises and poorly trained farmers and producers with little or no access to the benefits of the commercial sector.

Because there is no consensus on the definition of TQM, this study adopted the following TQM baseline definitions of Milakovich ${ }^{12}$ and Vouzas et al. ${ }^{13}$ :

- A total organisational approach for meeting customer needs and expectations that involves all managers and employees in using quantitative methods to improve the organisation's processes, products and services continuously.

- A new approach to the art of management that was developed during the Second World War and seeks to improve product and service quality and increase customer satisfaction by restructuring traditional management practices.

The study, being the first of its kind to be conducted in the South African agricultural sector, aimed to make original contributions to the body of knowledge on the subject of TQM implementation in the South African agricultural sector in general and in the Agri-SMME band in particular. These original contributions would be of methodological, theoretical and analytical value at both academic and managerial level.

This article is structured as follows: following the introduction, a brief literature review is provided, focusing on the TQM philosophy and SBP, which is one of the critical components of the philosophy. Thereafter, the SAEM is discussed in relation to TQM and SBP. A discussion follows on the research methodology used to collect and analyse data. Thereafter, the results of the study are presented, followed by an in-depth discussion. At the end of the article, conclusions are drawn and recommendations are submitted.

\section{Literature review}

In this section, TQM, SBP and the SAEM have been discussed. An overview of the various agricultural enterprises in
South Africa is provided firstly to give context to industry for implementing these models.

\section{Various agricultural enterprises in South Africa}

The South African agricultural sector has several branches, namely field crop husbandry, horticulture, animal husbandry, fish farming, game farming and agro-processing (p. 1).,14 Within these branches, there are 39 sectors that produce various products for domestic and export purposes. The largest export product groups involve raw sugar, fresh grapes, citrus fruits, nectarines, wine and deciduous fruits. Other important exports include: avocados, plums, maize, black tea, groundnuts, meat, pineapples, tobacco, wool and cotton. ${ }^{15}$

\section{Total quality management and strategic business planning}

After the Second World War, a new customer-centred management approach called TQM was developed and advanced by management and quality gurus, like Deming, Juran and Crosby, to mention a few. ${ }^{16}$ According to Kumar ${ }^{17}$ and Fotopoulos et al., ${ }^{18}$ these quality gurus had different areas of emphasis in the course of constructing the TQM framework. Notwithstanding that, there were numerous areas of common understanding amongst them, as outlined in the work of some authors, ${ }^{19}$ which resulted in a measure of synergy.

There are also different perspectives amongst various authors in the literature on what the principles of TQM are..$^{20,21,22}$ However, leadership, continuous improvement, customer focus, measurement, benchmarking and strategic planning are amongst many of the commonly cited TQM principles, whilst the benefits of adopting TQM are well documented. ${ }^{23,24}$ These benefits include, amongst others, improved effectiveness, flexibility and the competitiveness of a business to meet customer requirements. However, there are also barriers to successful implementation of TQM. These barriers include lack of effective leadership and management commitment, organisational politics, lack of continuous training and education and lack of planning, to mention only a few. ${ }^{20,25,26}$

Lack of planning was the research area of interest in this study. In quality management, strategic planning is referred to as 'strategy or planning' or 'policy and strategy' or 'business planning'. In the local TQM-based quality model, the SAEM, 'policy and strategy' is one of the 11 organisational criteria (see Figure 1). The criterion refers to how a business develops and reviews its plans and actions for each activity. ${ }^{27,28,29}$ This criterion or function, which is referred to as SBP in this article, has 10 focus areas, which were explored in the study (see Figure 2). ${ }^{30}$

Strategic business planning is associated with many benefits. Some authors noted that SBP gives SMMEs a competitive advantage and yet others reported that it results in opportunities for external funding and is associated with increased growth and business success. ${ }^{31,32,33}$ Strategic business planning is also linked to improved resource efficiency, 


\begin{tabular}{|c|c|c|}
\hline \multicolumn{3}{|c|}{ To be completed by all respondents } \\
\hline \multicolumn{3}{|c|}{ Strategic business planning } \\
\hline \multicolumn{3}{|c|}{$\begin{array}{l}\text { How the organisation formulates, deploys, reviews and turns policy and strategy } \\
\text { into plans and actions }\end{array}$} \\
\hline \multicolumn{2}{|l|}{ Step } & \multirow[t]{2}{*}{ Score } \\
\hline 10 & $\begin{array}{l}\text { Mission and organisation policy statements cover the } \\
\text { whole of the organisation and everyone understands } \\
\text { them. }\end{array}$ & \\
\hline 9 & $\begin{array}{l}\text { A process is in place to analyse 'best-in-class' strategy } \\
\text { and modify resultant unit plans to develop and sustain a } \\
\text { service excellence organisation. }\end{array}$ & \\
\hline 8 & The policy and strategy processes are benchmarked. & \\
\hline 7 & $\begin{array}{l}\text { A process is in place to modify policy and strategy based } \\
\text { on organisation and operational information. }\end{array}$ & \\
\hline 6 & $\begin{array}{l}\text { A process is in place to assess the continuing relevance } \\
\text { of plans based on organisation and operational } \\
\text { information. }\end{array}$ & \\
\hline 5 & $\begin{array}{l}\text { The organisation has policy statements and strategy that } \\
\text { cover the } 11 \text { performance improvement matrix } \\
\text { headings. }\end{array}$ & \\
\hline 4 & $\begin{array}{l}\text { A process exists, and is reviewed, that promotes a clear } \\
\text { understanding of the organisation's and unit's critical } \\
\text { success factors and policy statements that everyone } \\
\text { knows and understands. }\end{array}$ & \\
\hline 3 & $\begin{array}{l}\text { A process is in place to collect relevant external } \\
\text { information to enable a review of critical success factors } \\
\text { and organisation plans. }\end{array}$ & \\
\hline 2 & $\begin{array}{l}\text { A process is in place to collect relevant internal } \\
\text { information to enable a review of critical success factors } \\
\text { and organisation plans. }\end{array}$ & \\
\hline 1 & $\begin{array}{l}\text { The unit management team has developed a mission } \\
\text { statement and critical success factors. }\end{array}$ & \\
\hline \multicolumn{2}{|c|}{ Score (Assessment) Descriptions and options } & $\uparrow$ \\
\hline \multicolumn{2}{|c|}{$\begin{array}{l}\text { Not started ... or little progress across potential implementation } \\
\text { area. }\end{array}$} & 0 \\
\hline \multicolumn{2}{|c|}{ Some progress ... across about $1 / 4$ of potential implementation area. } & 1 \\
\hline \multicolumn{2}{|c|}{ Good progress ... across about $1 / 2$ of potential implementation area. } & 2 \\
\hline \multicolumn{2}{|c|}{$\begin{array}{l}\text { Substantial progress ... across about } 3 / 4 \text { of potential implementation } \\
\text { area. }\end{array}$} & 3 \\
\hline \multicolumn{2}{|c|}{ Fully achieved ... across entire potential implementation area. } & 4 \\
\hline \multicolumn{3}{|c|}{$\begin{array}{l}\text { Source: Adapted from South African Excellence Foundation (SAEF). Self-assessment } \\
\text { questionnaire \& workbook performance excellence. Pretoria: K \& M Print cc.; } 2000\end{array}$} \\
\hline \multicolumn{3}{|c|}{$\begin{array}{l}\text { FIGURE 2: The South African Excellence Model matrix chart used to assess the } \\
\text { performance of the agricultural small-, micro- and medium-sized enterprises } \\
\text { relevant to the strategic business planning function. }{ }^{30}\end{array}$} \\
\hline
\end{tabular}

internal communication, innovative thinking, customer value and articulation of organisational goals. ${ }^{34}$

However, SMMEs do not often implement SBP when compared with corporations. ${ }^{35,36,37}$ According to Gomera et $\mathrm{al}_{.}{ }^{38}$ the key to addressing the problems of poor performance and failure by SMMEs effectively is arguably the implementation of a strategic planning process. Other authors reiterated similar sentiments and that barriers to planning constitute lack of long-term vision, lack of time and expertise, inadequate knowledge of the planning process and reluctance to share strategic plans with employees. ${ }^{39,40}$

Figure 2 is an example of a self-assessment questionnaire that focuses on SBP.

\section{The South African Excellence Model}

Most organisations that adopt TQM use TQM-based quality models to measure and manage their performance on a continuous basis. The EFQM and MBNQA are two of the most popularly used quality models worldwide. In South Africa, organisations in various sectors and industries use the SAEM. ${ }^{41}$
The SAEM, ${ }^{7,30}$ which is a hybrid quality model of the EFQM and MBNQA models, has the following objectives:

- To form a basis for the SAEM.

- To serve as a framework to assist organisations in developing their vision and goals for the future in a tangible and measurable way.

- To serve as a framework to assist organisations in identifying and understanding the systematic nature of their business, key linkages and cause-and-effect relationships.

- To serve as a diagnostic tool to assess the current health of an organisation via a process of self-assessment.

The rationale to focus on SBP as a criterion over other criteria is that SBP is critical for and contributes strongly to the success of every business. It sets the standard for all other criteria for business success. Without this criterion, no achievable goals and milestones can be set. Besides, the overall study results revealed that the respondents, including those adopting TQM, were underperforming as far as business planning was concerned. Moreover, interrogation of business profiles revealed deficiencies in business planning abilities and risk management skills. Strategic business planning ensures community responsibility, customer satisfaction, people satisfaction, supplier and partner performance and business results. Hence, its ranking as priority criterion.

In this study, the SAEM was a critical research instrument used to achieve the set research objectives. These objectives were achieved through the research methodology to be discussed.

Figure 1 shows the SAEM, which comprises 11 criteria of different weightings, six (6) of which are enablers and five (5) of which are results. The enablers are leadership, policy and strategy, customer and market focus, people management, resources and information management and processes. As indicated earlier, this article focuses on the SBP (policy and strategy) criterion only.

The weighted points below the model for both the enablers and results are part of the model. They were assigned during the model development and are used as such.

\section{Methodology Research design}

The action research applied incorporated a mixed-methods research design in which quantitative and qualitative research methods were used together in an integrated manner for objectivity and to acquire a deeper understanding of how the agricultural enterprises viewed TQM and how they performed specifically concerning SBP.

\section{Participants and settings}

The population of the study was Agri-SMMEs in the former Ciskei and Transkei homelands, referred to as the Western 
Eastern Cape (WEC) and the Eastern Eastern Cape (EEC), respectively. Accordingly, the unit of analysis was AgriSMMEs.

For this study, the researchers used probability sampling to select two sub-samples (i.e. WEC non-TQM adopters and EEC non-TQM adopters) to measure the impact of TQM. In the case of the WEC TQM adopters, the entire subpopulation was included after the exclusion of survivalist Agri-SMMEs.

Subsequent to the above sampling, a sample was selected from the two sub-populations in the WEC and EEC regions. A total of 93 Agri-SMMEs in the WEC had adopted TQM. The majority (72) of these enterprises were very small survivalist enterprises, which had noticeably originally been established for food security or poverty-alleviation purposes. These enterprises were found not suitable for this study and were subsequently excluded.

The remaining 21 enterprises $(23 \%$ of the WEC subpopulation) constituted the sub-sample. The selection criterion was a total annual turnover of between R100 000 and R4 million. The 21 enterprises that had adopted TQM were regarded as the treatment sample for the WEC and were referred to as WEC TQM adopters.

A control sub-sample of 21 enterprises that had never adopted TQM in the WEC was randomly selected using the same criteria (i.e. size of total annual turnover or total gross asset value or size of full-time workforce). Thus, 42 enterprises constituted a research sample in the WEC (21 TQM adopters plus 21 non-TQM adopters).

In the EEC, a total of 84 Agri-SMMEs, which were recorded in a database of the EC province's Department of Agriculture and various non-government organisations, was identified to be suitable for this study. In this region, where TQM had never been adopted, 25 non-TQM adopters were randomly selected as a sub-sample using the selection criteria. In total, 67 Agri-SMMEs were, therefore, selected from the two subpopulations, that is, 42 enterprises from the WEC and 25 from the EEC.

Table 1 summarises the sub-populations and sub-samples from the EEC and WEC regions comprising the study area. The EEC had never adopted the TQM/SAEM, whilst the WEC had 41 non-TQM adopters.

\section{Reliability and validity}

Reliability and validity checks were applied to the research instruments. Cronbach's alpha for all three groups of

TABLE 1: Agricultural small-, micro- and medium-sized enterprises setting table.

\begin{tabular}{|c|c|c|c|}
\hline EC Agri-SMMEs & & & Total \\
\hline EEC (former Transkei) & WEC (former Ciskei) & & EC \\
\hline 84 non-TQM adopters & $\begin{array}{l}93 \text { TQM + } 41 \text { non-TQM } \\
\text { adopters }\end{array}$ & & 218 \\
\hline Subsample 25 & Treatment sample 21 & Control sample 21 & 67 \\
\hline
\end{tabular}

Agri-SMMEs, agricultural small-, micro- and medium-sized enterprises; EEC, the Eastern Eastern Cape; WEC, Western Eastern Cape; TQM, total quality management. respondents was $0.8518,0.7979$ and 0.8172 , respectively, the average being 0.8223 . A Cronbach's alpha coefficient of above 0.7 indicates an acceptable degree of reliability. ${ }^{42}$ This study also upheld internal, external and content validity that is advocated by other authors. ${ }^{43,44,45}$

\section{Data collection}

The internationally recognised SAEM was used to collect qualitative and quantitative data from Agri-SMMEs in the WEC that had adopted the TQM approach and from the WEC and EEC Agri-SMMEs that had not adopted TQM.

Data were collected by means of a questionnaire, semistructured interviews and direct observation. One part of the questionnaire was self-administered to collect demographic data, whilst the other part comprised the internationally recognised SAEM self-assessment matrix chart that was used to establish the extent of implementation of TQM on 10 focus areas of SBP. Face-to-face semi-structured interviews were used to acquire a deeper understanding of the respondents' perceptions of TQM and SBP. Direct observation was used as a means of supporting the answers to the questions by relating the analysis derived from the quantitative questionnaire and qualitative interviews. This instrument ensured that reliability measures were applied when collecting data. Observations included consent from the respondents prior to taking pictures, gathering of field notes and verification of the authenticity of documents, accuracy of measure and completeness of the documents.

\section{Data analysis}

Statistical Package for Social Sciences (SPSS)Version 17 was used to perform descriptive statistical analysis for central tendency. The mean scores of the SBP criterion of the SAEM were computed and analysed to determine the SBP performance of both the WEC TQM adopters and non-TQM adopters, as well as the EEC Agri-SMMEs on the scale of the SAEM self-assessment matrix chart. Analysis of variance was used to determine whether there were significant differences in the mean performance scores of the SBP criterion amongst and within the three research subsamples.

Non-parametric statistics were used to elucidate the outcomes of the parametric t-test. ${ }^{46,47}$ Accordingly, MannWhitney $\mathrm{U}$ and Kruskal-Wallis $\mathrm{H}$ tests were used to compare variables of the demographic data and mean performance scores of the SBP.

The qualitative data from the semi-structured interviews were analysed using content analysis. The analysis used key issues and themes from the semi-structured interviews.

\section{Findings}

This section presents the demographic data and the extent of orientation of the enterprises towards TQM, as well as the SBP performance of the enterprises. These findings resulted 
from a $100 \%$ response rate owing to the physical presence of the research team on research sites when a questionnaire was being administered.

\section{Respondents' demographic profile}

The respondents' demographic profile collected from a structured questionnaire included: age, gender, level of education, work experience and enterprise size.

\section{Age}

Most of the enterprises of WEC TQM adopters (28.6\%) and non-TQM adopters (23.8\%), and EEC non-TQM adopters (24.0\%) were operated by owners or managers. These operators were within the age groups 41-45, 46-50 and 51-55 years, respectively. In all three age groups, none of the respondents were younger than 35 years or older than 75 years. It is envisaged that the farming population could drop drastically with time. ${ }^{48}$ Therefore, the need to encourage participation of youth in agribusiness cannot be stressed enough.

\section{Gender composition}

The majority of respondents in all three research sub-samples were male. In the WEC, $66.7 \%$ of the enterprises that had adopted TQM were owned by males, whilst $76.2 \%$ of those that had not adopted TQM were also owned by males. In the EEC, $80 \%$ of the enterprises studied were owned by males. These results reflected the male dominance in the agricultural sector. $^{49}$

\section{Level of education}

In the WEC, $47.6 \%(n=10)$ of TQM adopters and 9.5\% $(n=2)$ of non-TQM adopters had completed grades $8-11 / \mathrm{N} 1-\mathrm{N} 2$, whilst the comparative percentage in the EEC was $12.0 \%$ $(n=3)$. In the WEC, $38.1 \%(n=8)$ of the adopters and $42.9 \%$ $(n=9)$ of the non-adopters had completed grade $12 / \mathrm{N} 3$ and in the EEC $32.0 \%(n=8)$ of the non-adopters had completed these levels. National technical certificates (N1, N2, N3 and higher) are vocational qualifications that one can choose to study at Technical and Vocational Education and Training (TVET) colleges. In the WEC, $47.6 \%(n=10)$ of the adopters and $9.5 \%(n=2)$ of the non-adopters had a diploma or bachelor's degree, whilst this percentage was $36.0 \%(n=9)$ amongst the non-adopters in the EEC.

In all three groups, the respondents' educational qualifications ranged between grade 8 and a master's degree. In addition, in all three groups, the majority of the respondents held diplomas or bachelor's degrees. These diplomas and bachelor's degrees included agricultural management, business management, teacher's diplomas and law. It was noticed that the respondents' level of education differed according to the type of the core business, with respondents in citrus enterprises being the most educated. For example, $86.0 \%(n=6)$ of the respondents in citrus enterprises had diplomas in crop production, whilst $14.0 \%(n=1)$ had master's degrees in economics.
The respondents' higher level of education could be attributed in part to the elimination of survivalist enterprises that are commonly run by people with a limited literacy level. In a study that included survivalist enterprises, Kwaru and Gogela ${ }^{50}$ found that only $16.9 \%$ of the 293 participants had a diploma or degree. Furthermore, 29.4\%, 37.5\% and $16.2 \%$ of the participants had completed grade 12 , grades 8-11 and grade 7 and below, respectively. In a study amongst the agricultural workforce in the EC, Jacobs et al. ${ }^{51}$ found that $91.26 \%$ had educational qualifications below grade 12 . These findings indicated that not much had changed in the education levels of workers in the agricultural sector of the EC province since the conduct of a previous similar study.

\section{Work experience of respondents}

In the WEC, $52.4 \%$ of TQM adopters and $47.6 \%$ of non-TQM adopters had 5-7 years' work experience in the agricultural sector, whilst $44.0 \%$ of the non-TQM adopters in the EEC had 5-7 years of work experience. Those with more than 11 years of work experience were $28.6 \%, 23.8 \%$ and $28.0 \%$, respectively.

The respondents who had more years of work experience in the business were expected to perform better than those who had fewer years of experience. In all fields, experienced owners or managers are expected to perform better by making use of experiential knowledge that can be acquired through personal experience, amongst other things. ${ }^{52,53}$

\section{Size of the agricultural small-, micro- and medium-sized enterprises}

In the National Small Business Act 102 of 1996, the size of enterprises in the agricultural sector is classified in terms of either annual turnover, gross assets or the size of the fulltime workforce. ${ }^{54}$

In terms of annual turnover, the majority of the enterprises in all three groups studied were categorised as very small, that is, $61.9 \%$ and $42.9 \%$ of WEC TQM adopters and non-TQM adopters, respectively, and $44.0 \%$ of EEC enterprises (see Figure 3).

\section{Performance in strategic business planning}

This section discusses the extent of SBP performance amongst the enterprises studied. These results were collected from self-assessment interviews.

Generally, all three enterprise groups, be it TQM adopters or non-TQM adopters, performed very poorly in the 10 SBP focus areas listed in Figure 2.

Against a maximum performance score of 17, WEC TQM adopters and non-TQM adopters, and EEC non-TQM adopters had performance scores of 3.58, 4.03 and 3.77, respectively (see Table 2).

Table 3 shows very poor performance scores for WEC TQM adopters and non-TQM adopters and EEC non-TQM adopters, namely $21.07 \%, 23.69 \%$ and $22.20 \%$, respectively. 


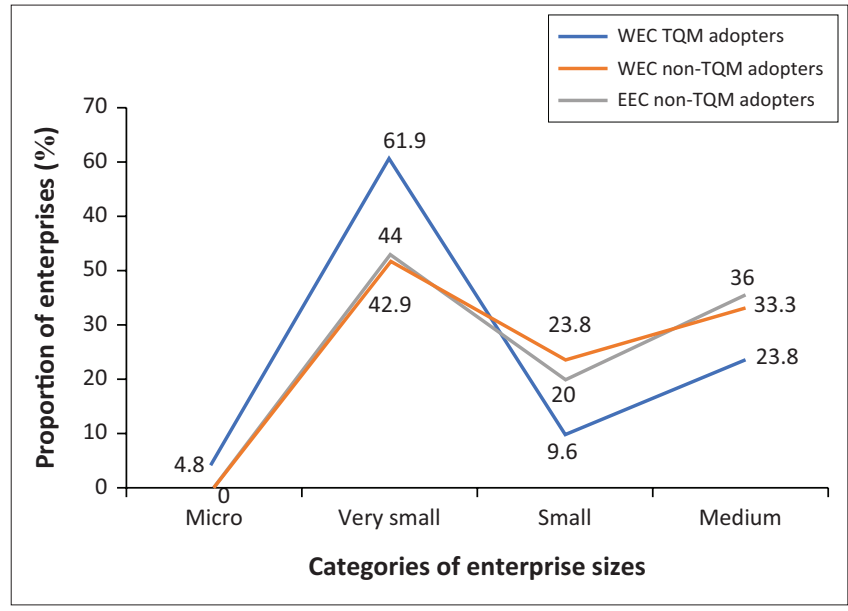

WEC, Western Eastern Cape; TQM, total quality management.

FIGURE 3: Distinction of the regions' enterprises according to their annual turnover.

TABLE 2: Results of the regions' strategic business planning performance scores.

\begin{tabular}{llcc}
\hline Regions & Adopters & Variable & Score \\
\hline WEC enterprise & TQM & Mean & 3.58 \\
& & s.d. & 1.64 \\
& \multirow{2}{*}{ Non-TQM } & SE & 0.36 \\
& & Mean & 4.03 \\
EEC enterprise & Non-TQM & s.d. & 1.52 \\
& & SE & 0.33 \\
Max score & - & Mean & 3.77 \\
\hline
\end{tabular}

EEC, the Eastern Eastern Cape; WEC, Western Eastern Cape; TQM, total quality management; $\mathrm{SE}$, standard error; s.d., standard deviation.

TABLE 3: Business planning achievement percentages of respondents in the Western Eastern Cape and Eastern Eastern Cape regions.

\begin{tabular}{lll}
\hline Regions & Adopters & Score \\
\hline WEC enterprise & TQM & 21.07 \\
& Non-TQM & 23.69 \\
EEC enterprise & Non-TQM & 22.20 \\
\hline Total & - & 100.00 \\
\hline
\end{tabular}

EEC, the Eastern Eastern Cape; WEC, Western Eastern Cape; TQM, total quality management.

The average achievement percentage for all the respondents was $22.32 \%$ against a total achievement percentage of $100 \%$.

Table 4 shows the results of the Mann-Whitney U test and that of the Kruskal-Wallis $\mathrm{H}$ test.

The Mann-Whitney U test was used to explain the outcomes of the parametric t-test, whilst the Kruskal-Wallis H test was used to compare variables of the demographic and business profiles, as well as the mean performance scores of the 11 criteria from the three research sub-samples.

The $\mathrm{p}$ value of 0.15 results in the business planning criterion showed no statistical significance $(p>0.05)$ in the difference in poor or no performance of the three enterprise groups. The respondents' underperformance in business planning indicated severely limited skills relevant to that function. There is notably a constraining business culture of not planning amongst the respondents. Total quality management and the
TABLE 4: Results of the Mann-Whitney $U$ and Kruskal-Wallis $H$ tests for comparing the business planning performance scores of Western Eastern Cape total quality management adopters and non- total quality management adopters, and Eastern Eastern Cape respondents.

\begin{tabular}{llc}
\hline Test & Statistical components & Business planning \\
\hline Mann-Whitney U & Mann-Whitney U & 163.50 \\
& Wilcoxon W & 394.50 \\
& Z & -1.44 \\
& $p$-value (2-tailed) & 0.15 \\
Kruskal-Wallis H & Chi-Square & 2.29 \\
& Df & 2 \\
& Asymp. Sig. & 0.32 \\
\hline
\end{tabular}

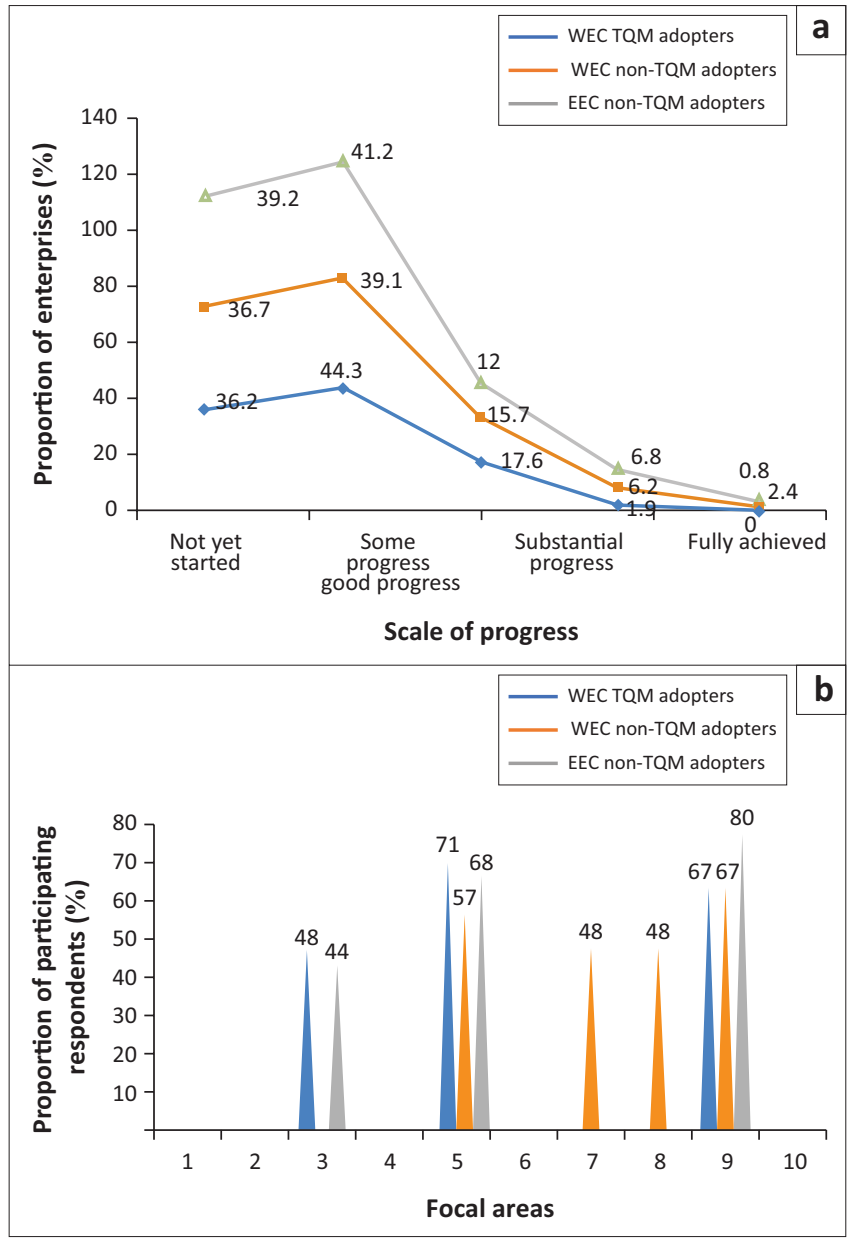

WEC, Western Eastern Cape; TQM, total quality management.

FIGURE 4: The respondents' (a) scale of progress made in business planning (b) most critical focal areas for improvement in 'business planning'.

SAEM involving an educational and training process that would change organisational cultures and build the necessary capacities offer excellent mechanisms to address the challenges being experienced concerning planning and risk management.

In similar local studies conducted in the education sector and military service using the excellence model, Ferreira ${ }^{8}$ and Eygelaar, ${ }^{9}$ respectively, reported higher achievement percentages of $44.0 \%$ and $30.0 \%$. In contrast, Ladzani ${ }^{55}$ found a low value of $12 \%$ in the local construction industry.

The findings on poor enterprise performance concerning the SBP function reflected the limited progress amongst enterprises in implementing the 10 focal areas of this function (Figure 4a). 
Figure $4 \mathrm{~b}$ depicts the five focal areas needing the most urgent attention and the percentage of participating respondents who had identified these focal areas. These focal areas, described in Figure 2, are (3) a process in place to collect relevant external information to enable a review of critical success factors and organisation plans; (5) the organisation with policy statements and strategies that cover the 11 performance improvement matrix headings; (7) a process in place to modify policies and strategies as a result of organisation and operational information; (8) the policy and strategy processes that are benchmarked and (9) a process in place to analyse 'best-inclass' strategy and modify resultant unit plans to develop and sustain a service excellence organisation.

Face-to-face semi-structured interviews were used to acquire a deeper understanding of the respondents' perceptions of TQM and SBP. The interaction with the respondents during the semi-structured interviews, transect walks and participant observation sessions revealed that lack of business planning abilities and risk management skills had complementary effects in frustrating the operations in several enterprises.

Semi-structured interviews further revealed a number of risk factors that were apparently caused by poor or no business planning. These potentially devastating risk factors were climate, stock losses because of theft and lack of sufficient markets. One of the root causes of poor or no SBP was a lack of business planning skills.

The results of the structured quantitative interviews showed that, when asked to rate their business planning skills on a scale of very weak to strong, $52.0 \%$ of the respondents in all three groups indicated poor business planning skills (either as very weak or weak). Yet, business planning is such a critical component of TQM that it features in many internationally recognised business excellence models rooted in the TQM philosophy.

Using both quantitativeand qualitative methodscomplemented each other by delivering objective results. Direct observation when these two approaches were used further strengthened the authenticity of the results.

\section{Discussion}

The purpose of this study was to investigate the current state of implementation of the TQM programme amongst selected Agri-SMMEs in the EC and their orientation towards TQM. The study further sought to identify the reasons for success or failure concerning the implementation of TQM and to make recommendations based on the findings.

In this study, the SAEM was used to collect qualitative and quantitative data from Agri-SMMEs in the selected regions of the study area. Self-assessment questionnaires were used to collect quantitative data, whilst face-to-face semistructured interviews were used to collect qualitative data. Measures taken to achieve reliable results from the questionnaires and semi-structured interviews included direct observations and examination of internal documents. All the research instruments were used concurrently on the same day the research team visited the Agri-SMMEs.

The results from the application of the SAEM for selfassessment indicated that the respondents, including the TQM adopters, were underperforming in SPB. The study revealed that the baseline data for the performance of business planning specifically were the lowest (22.32\%) against the world-class standard of $100 \%$. Moreover, the outcomes of face-to-face interviews revealed deficiencies in business planning abilities.

The respondents' underperformance in business planning indicated severely limited skills to perform this function. The relatively smaller enterprises were worst affected, notably because of a constraining business culture of not planning and a lack of resources and expertise to perform the function effectively. The positive and strong correlation between planning behaviour and firm size obliged the respondents ${ }^{56}$ to emphasise that lack of planning for quality was one of the barriers to successful implementation of TQM-based quality models.

Observation of and interaction with the respondents revealed that lack of business planning abilities had the complementary effect of frustrating the operations of several enterprises. Put differently, the basic and fundamental business planning questions of when, how, what and produced for whom failed to be considered appropriately, for example, in respect of when there was a tendency amongst producers of vegetables and field crops to flood markets with farm produce in summer when the production conditions were more favourable, with resultant unwanted surpluses that fetched poor prices or ran to waste. Conversely, in winter when the production conditions were less favourable, there would be limited supplies of farm produce whilst good prices would be offered by the markets, with the result that enterprises would find it difficult to make the most of the available business opportunity.

The negative effects of a lack of business planning and risk management skills, with the additional lack of entrepreneurial skills, were also experienced in livestock enterprises. The limitation of these skills amongst operators of SMMEs in non-agricultural sectors in South Africa has also been echoed by other authors..$^{57,58,59}$

Reasons for failure to implement TQM revealed in the study ranged from lack of funds and resources to management and physical barriers. The findings confirmed those of previous studies that reported that cultural barriers and lack of management are considered the most critical barriers to quality management. These are all leadership-related problems. The studies further confirmed that the main physical barriers to the successful implementation of TQM are inadequate infrastructure, inadequate financial resources and geographically dispersed sites. ${ }^{60,61}$ This study found that soft skills and resources were needed to deal with the management and physical barriers amongst the Agri-SMMEs studied. 
It was furthermore found that, generally, the business planning performance of relatively bigger enterprises was better than that of their smaller counterparts in that high capital investment and risk make such planning imperative in bigger enterprises. Such enterprises consequently had comprehensive short- to long-term business plans.

In contrast, some of the smaller enterprises had short-term informal and or verbal business plans. Wang et al. ${ }^{62}$ found that formal planners put more emphasis on setting goals than their informal counterparts who tend to view formal goals and ideals as less important. Lack of formal business plans also constrains prosperity because an enterprise cannot access credit from local financing institutions such as the Eastern Cape Rural Development Agency and the Eastern Cape Development Co-operation without such a plan.

\section{Conclusions and recommendations}

There is a strong notion in the literature that business planning is one of the functions that determines the path and future direction of any business, irrespective of its size and purpose. Contrary to this notion, the Agri-SMMEs studied were found to be dismally underperforming in this function, irrespective of whether they had adopted the TQM approach. The baseline data from the three groups studied underlined this fact.

This business conduct is characteristic of many businesses in the SMME band in many parts of the world. In this study, it presented itself as a barrier to successful implementation of the TQM amongst those Agri-SMMEs that had adopted the framework.

To turn around this situation, practical recommendations include the immediate implementation of interventions to address the problem of shortage of the necessary skills. These interventions should include training in business management skills that focus on TQM and performance excellence. All Agri-SMME role-players should commit themselves to implement excellence models. Such role-players should include Agri-SMME practitioners, agricultural extension officers, provincial and national agricultural departments and all suppliers of agricultural products and services. To further encourage the use of excellence models, annual competitions with reward incentives for performance excellence should be held at both provincial and national levels.

One of the limitations of the study was that it only focused on the business area of the Agri-SMME band. It did not explore agriculture as a discipline and excluded large-scale commercial agricultural enterprises and micro survivalists. Recommended areas for future research include an action research approach to TQM in Agri-SMMEs and an investigation into the suitability of TQM for relatively smaller agribusinesses.

\section{Acknowledgements}

The authors are grateful for the support received from the agricultural extension officers of the Eastern Cape Province's
Department of Rural Development and Agrarian Reform, and Community and Business Development Centre of the University of Fort Hare.

\section{Competing interests}

The authors have declared that no competing interests exist.

\section{Authors' contributions}

A.S. and W.L. conceived the writing of this article. A.S. developed the theory, the methodology and investigated the problem at hand. W.L. supervised the study, during and after write-up. Both W.L. and E.N. were involved with the revision and editing of the article. All authors discussed the results and contributed to the final manuscript.

\section{Ethical considerations}

The study was part of a DBL study by Awonke Sonandi that was done at the UNISA School of Business Leadership (SBL). The SBL approved the study protocol. The SBL did not issue an Ethical Clearance Certificate at the time of the study.

\section{Funding information}

This research received no specific grant from any funding agency in the public, commercial or not-for-profit sectors.

\section{Data availability}

The data collected and analysed in this study are available upon request from the corresponding author, M.L.

\section{Disclaimer}

The views and opinions expressed in this article are those of the authors and not necessarily reflect the official policy of any affiliated agency of the authors, and the Publisher/s.

\section{References}

1. AgriSETA. Agricultural sector strategic skills plan: 2011-2016. Prepared on behalf of the sector by the AgriSETA for submission to the Department of Higher Education and Training. Pretoria: AGRISETA, 2010; p. 1.

2. Simelane $P T$, Lall $M$, Kogeda OP. A mobile phone application for agricultural extension in marginalised rural areas of Pongola region, Zululand district, South Africa. S Afr J Agr Ext. 2019;47(1):137-150. https://doi.org/10.17159/24133221/2019/v47n1a495

3. Chimucheka T, Mandipaka F. Challenges faced by small, medium and micro enterprises in the Nkonkobe municipality. IBER. 2015;14(2):309-16. https://doi. org/10.19030/iber.v14i2.9114

4. Gill J. Quality follows quality: Add quality to the business and quality will multiply the profits. TQM J. 2009;21(5):530-539. https://doi.org/10.1108/17542730910983434

5. Firdausy $\mathrm{CM}$, Idawati R. Effects of service quality, price and promotion on customers' purchase decision of Traveloka online airline tickets in Jakarta, Indonesia. IJMSBA 2017;3(2):42-49. https://doi.org/10.18775/ijmsba.1849-5664-5419.2014.32.1004

6. Community Business Development Centre. Augmentation report for the South African Excellence Model. Alice: University of Fort Hare, 2008; p. 7.

7. South African Excellence Foundation (SAEF). SME criteria for small and medium enterprise performance excellence. Pretoria: K \& M Print cc.; 2000.

8. Ferreira M. A framework for continuous improvement in the South African higher education sector [unpublished thesis]. Pretoria: University of Pretoria; 2003.

9. Eygelaar SJD. The implication of the excellence model to enhance military health service delivery and performance excellence [unpublished thesis]. Johannesburg: Rand Afrikaans University; 2004

10. William JC. A retrospective view of the South African excellence model [unpublished MBA thesis]. Stellenbosch: University of Stellenbosch; 2008. 
11. Ladzani MW. Evaluation of small and medium-sized enterprises' performance in the built environment. [unpublished thesis]. Johannesburg: University of Johannesburg; 2009.

12. Milakovich ME. Total quality management in the public sector. Natl Prod Rev. 1991;10(2):195-215. https://doi.org/10.1002/npr.4040100208

13. Vouzas F, Psychogios AG. Assessing managers' awareness of TQM. TQM Mag 2007;19(1):62-75. https://doi.org/10.1108/09544780710720844

14. Ntombela S, Nyhodo B, Ngqangweni S, Phahlane H, Lubing M. Economy-wide effects of drought on South African Agriculture: A computable general equilibrium (CGE) analysis. J Dev Agric Econ. 2017;9(3):46-56. https://doi.org/10.5897/JDAE2016.0769

15. Department of Agriculture, Forestry and Fisheries. Agricultural education and training strategy for agriculture and rural development in South Africa. Pretoria: Government Printer, 2009; p. 6.

16. Kumar MR. Total quality management as the basis for organizationa transformation of Indian railways: A study in action research [unpublished thesis] Lismore: Southern Cross University; 2005.

17. Fotopoulos CB, Psomas EL. The impact of 'soft' and 'hard' TQM elements on quality management results. Int J Qual Reliab Manage. 2010;26(2):150-163. https://doi.org/10.1108/02656710910928798

18. Fonseca L. From quality gurus and TQM to ISO 9001:2015. A review of several quality paths. IJQR. 2016;9(1):167-180.

19. Oakland JS. Total quality management: Text with cases. 3rd ed. Oxford Butterworth-Heinemann; 2003.

20. Mittal J, Singh S. State of total quality management in pharmaceutical industry Literature review. IJMJ. 2012;2(3):82-91.

21. Dongare SN. Total quality management in library. Soc Growth Res J. 2012; I(III):111-117

22. Kumar R, Garg D, Garg TK. Total quality management in Indian industries: Relevance, analysis and directions. TQM J. 2009;21(6):607-622. https://doi. org/10.1108/17542730910995873

23. Vanichchinchai A, Igel B. Total quality management and supply chain management: Similarities and differences. TQM Mag. 2009;21(3):248-260. https://doi. org/10.1108/17542730910953022

24. Martínez-Costa $M$, Jiménez-Jiménez $D$. The effectiveness of TQM: The key role of organizational learning in small businesses. ISBJ. 2010;27(1):98-125. https://doi. org/10.1177/0266242608098348

25. Bhat KS, Rajashekhar J. An empirical study of barriers to TQM implementation in Indian industries. TQM Mag. 2009;21(3):261-272. https://doi. org/10.1108/17542730910953031

26. Kruger DJ, Ramdass K. Establishing a quality culture in higher education: A South African perspective. Proceedings of PICMET '11: Technology Management in the Energy-smart Word (PICMET), July 31-August 04, 2011 Portland, Oregon.

27. Department of Agriculture. Guide for the South African excellence model in agribusinesses. Pretoria: Government Printer; 2009.

28. McCarthy M, Thomson D. Risk management and farming families: Perceptions and practices [homepage on the Internet]. Canberra: Rural Industries Research and Development Corporation. 2007 [cited 2010 Jun 15]. Available from: https:// rirdc.infoservices.com.au/downloads

29. Arumugam V, Chang HW, Ooi K, Teh P. Self-assessment of TQM practices: A case analysis. TQM J. 2009;21(1):46-58. https://doi.org/10.1108/175427309 10924745

30. South African Excellence Foundation. Self-assessment questionnaire \& workbook performance excellence. Pretoria: K \& M Print cc.; 2000.

31. Veskaisri K, Chan P, Pollard D. Relationship between strategic planning and SME success: Empirical evidence from Thailand. International DSI/Asia and Pacific DSI. 2007:1-14.

32. Jasra JM, Khan MA, Hunjra Al, Rehman RAU, Azam RI. Determinants of business success of small and medium enterprises. IJBSS. 2011;2(20):274-280.

33. Brinckmann J, Kim SM. Why we plan: The impact of nascent entrepreneurs' cognitive characteristics and human capital on business planning. Strat Entrepreneurship J. 2015;9(9):153-166. https://doi.org/10.1002/sej.1197

34. Bright P. An investigation into the strategic planning practices of Rotorua based small businesses. Rotorua: Waiariki Institute of Technology Research Report; 2014.

35. Beaver G. Management and the small firm. Strat Change. 2003;12(2):63-68 https://doi.org/10.1002/jsc.623

36. Goodluck IJ, Eromonsele UJ, Sixtus O. Investigation into the use and implementation of business plan in Ekpoma [homepage on the Internet]. Ekpom Town: Institute for Governance and Development. 2019 [cited 2019 Jun 20] Available from: www.igdonline.org/index.php/iigd/article/review/31

37. Carreras ABL, Arroyo JC, Blanco JEE. Influence of the strategic planning and the management skills as factors internal of business competitiveness of SMEs. Contaduríay Administración. 2018:63(3):9-10.
38. Gomera S, Chinyamurindi WT, Mishi S. Relationship between strategic planning and financial performance: The case of small, micro- and medium-scale businesse in the Buffalo City Metropolitan. SAJEMS. 2018; 21(1). https://doi.org/10.4102/ in the Buffalo City
sajems.v21i1.1634

39. Mazzarol T. Strategic management of small firms: A proposed framework for entrepreneurial ventures. Paper presented at: Brisbane 2004. Proceedings of the 17th Annual SEAANZ Conference; 2004 Sept 26-29; Brisbane Graduate School of Business, Queensland, Australia; 2004.

40. Agwu ME. Analysis of the impact of strategic management on the business performance of SMEs in Nigeria. ASMJ. 2018;17(1):1-12.

41. Ladzani MW. Benchmarking the South African Excellence Model against worldclass best practice business excellence models. Environ Econ. 2016;7(4):8-19. https://doi.org/10.21511/ee.07(4).2016.01

42. Look JO, Schiffman EL, Truelove EL, et al. Reliability and validity of axis of the research diagnostic criteria for temporomandibular disorder (RDC/TMD) with proposed revisions. J Oral Rehabil. 2010;37(10):744-759. https://doi.org/10.1111/ j.1365-2842.2010.02121.x

43. Burns N, Grove SK. Understanding research. 2nd ed. Philadelphia, PA: Saunders; 1999

44. Taherdoost $\mathrm{H}$. Validity and reliability of the research instrument; how to test the validity of a questionnaire/survey in a research. IJARM. 2016; 2016;5(3):28-36. https://doi.org/10.2139/ssrn.3205040

45. Taylor R, Sanders D, Myers T, et al. The reliability and validity of integrated external and internal load ratios as measures of fitness in academy rugby union players. J Strength Cond Res. 2020;34(6):1723-1730. http://doi.org/10.1519/ JSC.0000000000002391

46. Beukman TL. The effect of selected variables on leadership behaviour within the framework of a transformational organisation [unpublished thesis]. Pretoria: University of Pretoria; 2005.

47. Nordstokke DW, Zumbo BD, Cairns SL, et al. The operating characteristics of the non-parametric Levene test for equal variances with assessment and evaluation data. Practical Assess Res Eval. 2011;16(5):1-8. https://doi.org/10.7275/5t99-zv93

48. Mngomezulu S. 2010. Formal marketing of cattle by communal farmers in the Eastern Cape Province of South Africa: Can they take part? [unpublished MSc thesis]. Wageningen: Wageningen University; 2010

49. Eastern Cape Department of Agriculture. Assessment of the Eastern Cape provincial growth and development plan. Bhisho: Government Printer; 2011.

50. Kwaru VV, Gogela PS. Report of a national strategy on education and training in agriculture and rural development. Pretoria: Government Printer; 2002.

51. Jacobs E, Punt C. A profile of the Eastern Cape Province: Demographic, poverty, economic, inequality and unemployment from 2000 till 2007 [homepage on the Internet]. 2009 [cited 2010 Jul 16]. Available from: http://www.elsenburg.com

52. Apostolou B, Blue MA, Daigle RJ. Student perceptions about computer testing in introductory managerial accounting. J Acc Ed. 2010;27(2):59-70. https://doi. org/10.1016/j.jaccedu.2010.02.003

53. Blocher E, Shastri K, Stout DE et al. Instructional case: Blue Ridge revisited Integrating ABC and OROS Quick ${ }^{\oplus}$ software. J Acc Ed. 2009;27(2):85-103. https:// doi.org/10.1016/j.jaccedu.2010.02.002

54. South Africa. Department of Trade and Industry (DTI). National Small Business Act No. 102 of 1996. Cape Town, 1996.

55. Ladzani MW. Evaluation of small and medium-sized enterprises' performance in the built environment [unpublished thesis]. Johannesburg: University of Johannesburg; 2009.

56. Temtime T, Solomon GH. Total quality management and the planning behavior of SMEs in developing economies. TQM Mag. 2002;14(3):181-191. https://doi. SMEs in developing economies.
org/10.1108/09544780210425900

57. Majama NS, Magang TIT. Strategic planning in small and medium enterprises (SMEs): A case study of Botswana SMEs. J Manag Strat. 2017;8(1):74-103. https:// doi.org/10.5430/jms.v8n1p74

58. Akolo AO, Mulili B, Kiboi A. Effects of strategic planning on performance of small and medium enterprises: The case of SMEs in Nairobi. J Strat Manag [seria online]. 2018;2(4):65-84. Available from: https://stratfordjournals.org/journals/ index.php/journal-of-strategic-management/article/view/200

59. Bushe B. The causes and impact of business failure among small to micro and medium enterprises in South Africa. APSDPR. 2019;7(1):1-26. https://doi. org/10.4102/apsdpr.v7i1.210

60. Twaissi NMM. An evaluation of the implementation of total quality management (TQM) within the information and communication technology (ICT) sector in Jordan [unpublished PhD thesis]. West Yorkshire: University of Huddersfield 2008.

61. Karani SR, Bichanga WO. Effects of total quality management implementation on business performance in service institutions: A case study of Kenya Wildlife Services. IJRSM. 2012;1(1):59-76. https://doi.org/10.5861/ijrsm.2012.v1i1.61

62. Wang C, Walker EA, Redmond J. Explaining the lack of strategic planning in SMEs: The importance of owner motivation. International Journal of Organisationa Behaviour. 2011;12(1):1-16. 